\title{
Stakeholder participation in long term planning of water infrastructure
}

\author{
G. J. Roovers ${ }^{1,2^{*}}$ and M. W. van Buuren ${ }^{3}$
}

\begin{abstract}
Taking stakeholders into account while making plans helps to increase legitimacy. But in long-term planning involvement of stakeholders encounters severe problems. It encounters problems because of the misfit in planning horizons between asset manager and stakeholders. Furthermore, the ambiguous and indistinct character of stakeholders' ambitions makes successful participation difficult. This article explores ways to deal with this problematic nature of stakeholder participation in long-term planning within modern water infrastructure asset management. Following theory, this article presents a typology with four types of possible styles for asset management which also gives rise to specific forms of stakeholder participation: (1) monofunctional - asset manager realizes the main function of its assets and manages them with only an eye on the principle core function of the asset; (2) integrated asset manager realizes an integral approach of its assets, and manages them with this integral approach in mind; (3) accommodating - asset manager realizes the main function of its assets but accommodates other functions as well; and (4) learning - asset manager is responsible for the main function of its assets, but invites stakeholders to participate, intertwine other functions and to manage, explore and develop the system jointly. The feasibility of these styles of asset management is assessed by looking at four cases with a long-term perspective within Dutch water management. We derived possible characteristics of these styles and accompanying stakeholder participation, seen from a long-term perspective. These characteristics give appropriate directions to deal with the problematic nature of stakeholder participation in long-term issues within modern water and infrastructural asset management.
\end{abstract}

Keywords: Long term planning, Public asset management, Stakeholder participation, Water management

\section{Background}

Water management and professional asset management Issues on water management are becoming more and more complex (Teisman et al., 2013). Water systems can be characterized by many (unknown) connections between physical, ecological and social processes. In such complex systems uncertainties about behaviour and relations are huge, effects may be unpredictable and emergent behaviour appears (Rotmans et al. 2005, Teisman et al., 2013, Roovers, 2012). Because of these increasing uncertainties and complexity planning of new infrastructure and maintenance of existing infrastructure has to deal with large, and often unknown, unknowns and with emergent

\footnotetext{
*Correspondence: geert.roovers@anteagroup.com

${ }^{1}$ Antea Group, Oosterhout, Netherlands

${ }^{2}$ Saxion University of Applied Science, Deventer, the Netherlands

Full list of author information is available at the end of the article
}

developments. Furthermore, investments in water management are high, and will become higher due to climate change, growing technological opportunities and higher demands by society (Dewulf et al. 2010). These increasing uncertainties and huge costs ask for a long term focus in water asset management (e.g. 50-100 yrs.). This is why Herder and Wijnia (2012) state that 'design of infrastructure has to be right for a very long time'.

At the same time water infrastructure affects multiple (potential) public interests, in a positive or a negative way. To safeguard their license to operate, public asset managers have to invest in stakeholder participation. But this participation is quite problematic when it comes to decisions with a long-term perspective. There are at least four reasons for this: (1) Substantive uncertainties with regard to long-term decisions are huge, so in what decisions stakeholders
焦 Springer

(C) 2016 Roovers and van Buuren. Open Access This article is distributed under the terms of the Creative Commons Attribution 4.0 International License (http://creativecommons.org/licenses/by/4.0/), which permits unrestricted use, distribution, and reproduction in any medium, provided you give appropriate credit to the original author(s) and the source, provide a link to the Creative Commons license, and indicate if changes were made. 
have to participate? Possible measures and possible impacts have a wide range, and (almost) anything can be arguable in the long-term. Boundaries for the participation agenda cannot be defined unambiguously. (2) Strategic uncertainties are huge. Most stakeholders don't have a clue about their interests and goals on a long term. And which stakeholders are at stake in the long term? Ultimately, participation is always biased in favour of current generations, as future generations simply cannot participate (Franssen et al. 2013). (3) Institutional uncertainties are huge. Rules, legislation, trust and reputation: the institutional context in which the results from the planning and participation will take place, is largely unknown. The same holds true for budgetary constraints. (4) Due to the long term horizon of planning, the urgency to participate is low for most stakeholders. There is no possible gain for them in the short term.

This problematic nature of stakeholder participation in asset management in which long-term issues play a role, forms the point of departure for this paper. We will present four different styles of public asset management, which help us to analyse four cases of asset management with a long term focus in which these styles were applied. We subsequently explore how stakeholder participation in these cases was organized, the impact of it and how the long-term was dealt with. By doing so, we answer the question how public asset managers (can) deal with stakeholder participation in the shadow of long-term challenges. By analysing different cases, in which different styles of asset management are applied, we are able to figure out whether different styles have different effects when it comes to realize stakeholder satisfaction in a context of long-term uncertainties.

\section{Challenges of public asset management Asset management}

Asset management takes a life-cycle approach of assets as its starting point (Falls et al. 2001). Baskarada et al. (2006) define assets as 'everything which has economic value and is owned by an organization.' The British Standard Specification PAS 55 defines asset management as 'the systematic and coordinated activities to manage assets and their performance, risks and costs during their life cycle optimally, considering the strategic goals of the organisation' (BS EN ISO 9001:2008 2008). Due to the rapid development of the field of infrastructure (asset) management since the 1990's, no clear definition of infrastructure asset management exits (Schraven et al., 2013). They state that the numerous definitions of asset management share common ground with regard to two aspects: (1) assets are used to achieve organizational goals and (2) managing assets means considering the complete asset life cycle. Herder and Wijnia (2012) refer to the strategic use of asset management as 'an integral approach in which asset management is used to contribute to organisational goals'. Asset management thus is about a life-cycle approach, and is linked to strategic organizational goals.

\section{Public asset management}

Asset management focuses on the lifecycle of assets, and puts investments in assets in their life-cycle perspective. It considers the performance of assets within the context of their risks and costs. Moon et al. (2009) refer to the maximisation of performance of an infrastructural system with available budgets as the main purpose of asset management. Herder and Wijnia (2012) identify specific characteristics of infrastructural asset management: (1) assets have a very long lifespan of 50-100 years, (2) assets have no resale value, and (3) infrastructural systems are evolutionary systems. El-Akruti and Dwight (2010) state that, due to the complexity of infrastructure networks, a holistic approach of asset management is needed, but often fails. This is because asset management is often mainly focused on maintenance (Frolov et al. 2009). Herder and Wijnia (2012) consider asset management as 'getting the best value out of assets'. Effective asset management should fulfil a strategic role, and in infrastructure these goals are often derived from the public interest (Herder and Wijnia 2012, Too, 2010). In this, a narrow focus of asset management can hamper a more integrated view on public interests. And a broadened, integrated focus upon creating public value by managing public assets - from different interests and desired public values is not yet broadly considered in asset management literature. We refer to this broadened approach of asset management - starting from public interests - as public asset management.

\section{Dealing with long term uncertainties}

Actors have different perceptions of time and focus upon different time horizons (Eshuis and Van Buuren, 2014). Furthermore, a clear definition of 'long term' doesn't exist (van Dorsser, 2015). Van Dorsser (2015) defines the long term as a period of 5 to 30 years ahead and the very long term as a period of $30-200$ years ahead. Usual design periods within water management and water infrastructures range from 80 to 200 years, and thus concern a very long term. The longer the time horizon which is dealt with, the larger its uncertainties. Koppejan and Klijn (2004) distinguish between substantive uncertainties, strategic uncertainties and institutional uncertainties. Teisman (2007) discerns two strategies which are used to deal with uncertainties in complex systems: (1) reduction of complexity into subsystems and control of these subsystems. In this approach control of subsystems 
should lead to control of the whole system, including its uncertainties. Long term uncertainties and different possible futures are reduced to single principles for decision making. (2) Acceptance of the inherent complexity of complex systems and their uncertainties. Different futures are considered and anticipated on while making decisions. Hoppe and Hisschemöller (1996) discern uncertainties about facts and uncertainties about values. They have derived a typology of problems by distinguishing these uncertainties (see Fig. 1). According to this typology four different types of appropriate problem-solving strategies are distinguished: solving problems by rules, accommodate, negotiate or learning, see Fig. 2.

Because of the long term unknown future substantive uncertainties in infrastructural asset management are high. But as we saw, strategic and institutional uncertainties in water management can be high too, as is the case with uncertainty about values (ambiguity). Furthermore, water systems can be considered as complex systems. Thus, for infrastructural asset management, a problem solving strategy based on learning and acceptance of complexity, may be expected to be the most appropriate. At the same time, asset management often departs from a rather technocratic orientation, whereby asset managers often opt for a complexity-reducing approach, which doesn't leave much room for acknowledging and anticipating uncertainties (Duijn, M., M.W. van Buuren, M. Sparrevik, A. Slob, G.J. Ellen, A. Oen, Getting caught up in the game: Managing non-formal dynamics in the remediation of contaminated sediments in Oslo Harbor (forthcoming)). This raises questions about proper and effective public asset management strategies dealing with long term problems.

\section{Stakeholder participation is needed, but generates additional problems}

Infrastructure management is changing from 'investing in new infrastructure' to 'maintenance of existing infrastructure' (Herder and Wijnia, 2012, Roovers and van Buuren, 2014). Attention for stakeholder participation during the whole life-time of infrastructure assets should thus be rising. Stakeholder participation has many benefits. It enhances the quality of planning by incorporating more views and information (Koppejan \& Klijn 2004). Stakeholder participation enhances acceptance of planning, because it takes more interests and perspectives into account (Bruijn, H. de and ten Heuvelhof 2007). Furthermore, stakeholder participation has the potential to increase social capital and civic competences: it can promote learning and the development of necessary skills (Irvin \& Stansbury, 2004). Finally, stakeholder participation enhances the democratic rate and legitimacy of planning (Van Buuren et al. 2014). The need for stakeholder participation in infrastructure asset management is even strengthened because 'current decisions on infrastructural assets highly contain the decision space for future decisions' (Herder and Wijnia, 2012).

Last decades many methods are developed to organize successful stakeholder participation. These methods vary in depth and width of participation. This variety can differ from the degree of participation, the nature of participation, the theoretical basis (normative and/or pragmatic participation) and the objectives of participation (Reed, 2008). Arnstein's 'ladder of participation' (Arnstein, 1969) described a continuum of increasing stakeholder involvement, from passive dissemination of information (which she called 'manipulation'), to active engagement (called 'citizen control'). Arnstein's typology has been widely used, for example in Edelenbos and Klijn (2006). Edelenbos and Klijn used a ladder of stakeholder involvement ranging from 'informing stakeholders' to 'coproduction together with stakeholders'. Rowe and Frewer (2000, in: Reed, 2008) identify different types of stakeholder participation by the direction of communication flows. They discern 'communication'

knowledge

\begin{tabular}{l|c|c|}
\multicolumn{1}{c}{ No uncertainties } & Much uncertainties \\
\cline { 2 - 3 } No uncertainties & Structured problem & $\begin{array}{c}\text { Semi-structured } \\
\text { problem }\end{array}$ \\
\cline { 2 - 2 } values & $\begin{array}{c}\text { Semi-structured } \\
\text { problem }\end{array}$ & Unstructured problem \\
\cline { 2 - 3 } Much uncertainties & \\
\hline
\end{tabular}

Fig. 1 The typology of problems discerned by Hoppe and Hisschemöller (1996) 
knowledge

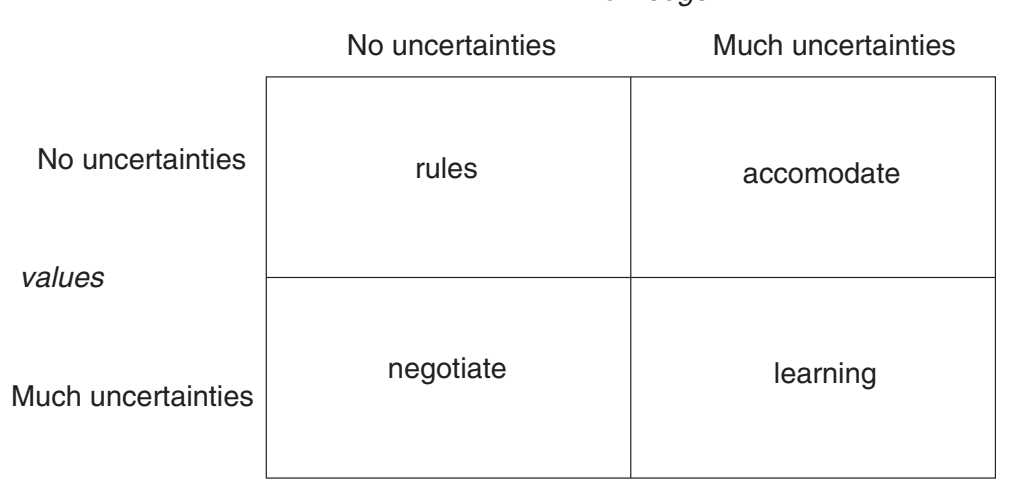

Fig. 2 Strategies for appropriate problem solving within the typology of problems discerned by Hoppe and Hisschemöller (1996)

(information dissemination to passive recipients), 'consultation' (gathering information from participants) and 'participation' (two-way communication between participants). The latter is often labelled coproduction, which seems to be a less ambiguous label for more equal interaction between public organizations and stakeholders (Edelenbos and Klijn, 2006).

We thus may conclude that public asset management in water management should not only connect asset management with public interests and a long term perspective, but with stakeholder participation too. And as already noted, this stakeholder participation with regard to long-term issues is problematic, as uncertainties are huge and urgency is low. In this, the relation between stakeholder participation and using a long-term horizon seems to be some sort of a trade-off. Stakeholder participation might be easier when the agenda is about issues which are urgent and without many uncertainties. Long-term planning issues which are less urgent and have many uncertainties - might be more easily dealt with when stakeholders are kept at a distance and experts are getting the room to analyse and deal with them. But, in this trade-off the benefits of stakeholder participation are not (fully) used. To analyse this trade-off and to develop appropriate directions for stakeholder participation in long-term issues, we derived four styles of public asset management.

\section{Four styles of public asset management}

Public asset management should anticipate on public interests, connect them with organisational goals and use appropriate stakeholder participation. Within this, stakeholder participation is problematic, due to large longterm uncertainties and low urgency. Herder and Wijnia (2012) state that in the most elementary definition asset management is 'getting the best value out of assets'. This holds for all assets in all fields where the term asset management has been coined. What does differ is what is considered as best value. This depends highly upon the specific perceptions and ambitions of actors involved, thus can change during time and can be seen as a strategic organizational goal as well. In extremis, asset management can be used in two ways:

1. To maintain the status-quo and to focus upon the current functions. Thus, if interests of other stakeholders do not change, or external developments do not ask for change, the asset manager feels only responsible for the primary function of his assets. We could call this 'closed' asset management.

2. The asset manager is open for suggestions to add other functionalities to his assets and is willing to intertwine other interests and values to the primary functions of his assets. We could call this 'open' asset management.

Furthermore, following the typology of problems by Hoppe and Hisschemöller (1996), we can discern:

1. Explorative asset management: asset management is focused on learning about the system and assets and continuously renewing and adapting the system and its core functions to new circumstances and desires;

2. Exploiting asset management: asset management is aimed at getting as much value out of the existing assets as possible, given the pre-set goals and anticipated uncertainties. Getting the performance of the system accomplished as effective as possible 'value for money'.

This may lead to four types of asset management, see also Fig. 3.

\section{- Monofunctional asset management:}

The asset manager realizes the main function of its assets and manages them with only an eye on the principle 


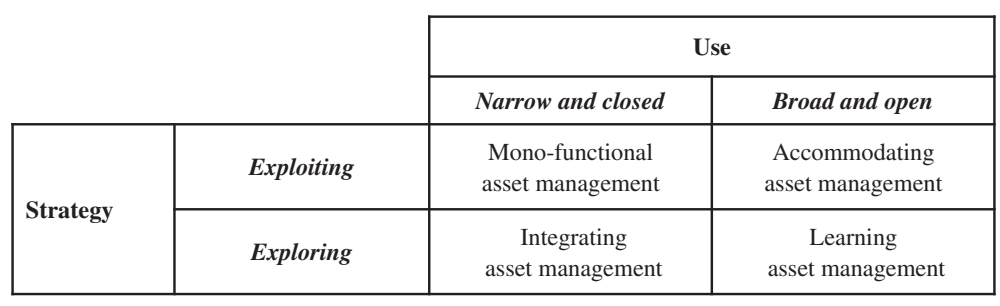

Fig. 3 A typology of four types of asset management

core function of the asset. The focus of the asset manager is on its own assets. This functional and strictly defined focus is also the leading focus on many classical accounts of asset management that focus upon efficiency, risk-reduction and functional optimization (see for example the British Standard Definition, BS EN ISO 9001:2008 2008).

\section{- Integrated asset management:}

The asset manager realizes an integral approach of its assets, and manages them with this integral approach in mind. This integral approach can incorporate other public values, such as sustainability or spatial quality. The focus of the asset manager can still be on its own assets, but can be focused on the environmental impacts of the assets as well. This approach, for example, can be seen in recent thinking about blue-green infrastructures (Voskamp and van de Ven, 2015).

\section{- Accommodating asset management:}

The asset manager realizes the main function of its assets but is open to accommodate other functions - as desired by other actors - as well. Its focus is beyond its own assets and on a regional, system or even national perspective as well. Often collaborative approaches are used to invite other stakeholders to articulate their interests and to look for opportunities to facilitate them by accommodating new functionalities (Bressers and Lulofs 2010).

\section{- Learning asset management:}

The asset manager is open for a broad, inclusive development of his assets, invites stakeholders to participate, intertwine other functions and to manage, explore and develop the system jointly. Its focus is beyond its own assets and on regional, system or even national perspectives as well. In this type of asset management problem definition and searching for solutions are continuously intertwined. An example of such an open approach can be seen in the area-based approach of Dutch housing associations (van Overmeeren 2011).
These four types of asset management may ask for different appropriate stakeholder participation strategies dealing with long term uncertainties. To explore how stakeholder participation is applied in combination with these different types of asset management, four typical cases that reflect these different types of asset management were studied. In these cases the way which is dealt with long term uncertainties, is explored too. The next paragraphs describe the results of these cases and how the long-term was dealt with.

\section{Methods}

In the previous chapter we derived a typology of asset management, based on the way new functions are taken into account and the way the asset manager opens its management for joint learning about his assets. The typology is derived from the typology of dealing with uncertainties by Hoppe and Hisschemöller (1996). As we have seen, this leads to four types of asset management: mono-functional, integrated, accommodating and learning asset management.

We have selected four cases in which one of the four asset management strategies was used, and looked at the way stakeholder participation was used. The typology of the ladder of participation (Arnstein, 1969, Edelenbos \& Klijn, 2006) was used to account for the extent of participation in the cases, distinguished between participation about the purpose of the asset manager and about the proposed solutions. In addition we looked at the way the long term perspective was dealt with. In this we used the typology of Teisman (2007): long term uncertainties can be 'reduced and simplified' or 'embraced and anticipated upon'. Our case selection thus was theory driven, as we were interested in the question which type of stakeholder participation is used and how it fits in a specific asset management strategy. Furthermore, we take the opportunity to see what influence the long-term perspective might have on the room for stakeholder participation.

The empirical material for these case studies was very diverse. We relied upon existing case studies conducted for other research projects. These case studies were based upon document analysis and active participation of the authors as consultant and expert. In some cases 
interviews were used. In addition, we did secondary analyses of existing sources (evaluation studies, master theses, et cetera, see references).

Within the cases we address the following specific aspects:

- a short characterisation of the case;

- description of the asset management strategy, along the lines of closed-open and exploiting-exploring;

- description of the degree of stakeholder participation, the way in which the long term perspective was dealt with, and its results. For this we used the distinction between 'communication', 'consultation' and 'coproduction' for the extent of participation, and the terms of 'acceptance' and 'resistance' for the extent to which the participation influences the final (or preliminary) results. The extent of participation is given for the participation about the purpose of the asset manager and for the development of solutions within the case. In the way in which the long term perspective was dealt with in the case, we follow Teisman (2007): 'reducing' or 'anticipating'.

- fit and appropriateness between the asset management strategy and the participation strategy used.

\section{Results}

In this chapter we present four cases dealing with assets in water management. In all cases a long term perspective was present.

\section{Dike improvements in the Netherlands (Mono-functional asset management)}

This case description is based on Driessen and A.J. de Gier (1997), van Eeten, M. van (1997), Meurs, R. van (2002) and van Heezik (2007).

\section{Characterisation}

The Netherlands has a large history on adjusting and reinforcing its dikes throughout the last decades, following new insights on river discharges and technical design. From the '70's several programs have been carried out throughout the whole country. And in every program, new discharge standards and technical standards were leading to new dike improvements. The dikes had to be adjusted to the appropriate safety norms following new hydrological or political views. To keep up with these new insights from the '70's four programs have been carried out:

1. River dike reinforcements (1970's-1993)

2. Deltaplan Large Rivers (1995-2000)
3. Flooding Protection Program 1 (2001-2007)

4. Flooding Protection Program 2 (2007-now)

This case focuses on programs 2 and 3 (period 19952007). In these programs a long perspective was present: all dike improvements had a design horizon of at least 50 years ahead and had to anticipate on long term developments in climatic circumstances.

\section{Asset management strategy, stakeholder participation and dealing with long term uncertainties}

In the first dike reinforcement program (1970's-1993) focus was on getting the safety standards, without any eye for other functions. Dikes were designed without stakeholder participation, according to safety standards. Demolition of houses and landscape often were the result. But, these improvements did not come easy. In the '80s the impact of the improvements on landscape, housing and ecology lead to fierce local resistance and deadlocks in decision-making. These debates lead to new ways of planning, in which environmental impact assessment and stakeholder participation got a strong position. So, from the '90's stakeholder participation got a strong foothold in Dutch dike reinforcement planning. The asset management strategy from then can be defined as closed and exploiting. Stakeholder participation was aimed at minimizing impacts of the dike reinforcements on housing and landscape, in order to prevent or minimize societal resistance. If possible, local nuisances such as intensive traffic on dikes, were solved and ecological improvements at and around the dike reached. But in essence, stakeholder participation remained focused on predefined formal goals: to improve the dikes in such a way that they met the legal norms. Participation was thus mainly aimed at safeguarding the implementation of the predefined strategy of dike enforcement.

This case deals with short term urgent measures: the national government had to realize the legal norms on flood safety within fixed timeframes. In this, the long perspective is taken into account. The design of the dikes had to be right for $50-100$ years. Long term uncertainties were translated into short term restraints for designing dikes and constructions. Because of the short term measures and their possible impact, it is urgent for stakeholders to participate. Local and regional developments alongside the dikes were considered based on existing policy programs, mostly not reaching beyond 10 years ahead.

\section{Fit and appropriateness}

The mono-functional management strategy of the dike reinforcements from 1995 to 2007 was accompanied by intensive stakeholder participation aimed at minimizing 
its external impacts. Due to this intensive participation approach, based on consulting, dike-improvements became successful examples of stakeholder participation, in which fast implementation was combined with local support and a high esteemed result. The main reasons for this success were the widely accepted main goal of flood protection and the solution of dike improvement to reach this goal. Problem and main solution were not discussed, only the implementation of this solution needed care.

From this case the following essentials can be learned:

- A closed way of asset management can be successful in maintaining the desired level of functioning and solving additional local problems, with broad local acceptance and quality when there is consensus about the main goals of the asset manager.

- within this approach new ways of dealing with functions, cross-functional improvements and system-changes might not come into sight.

- this way of asset management functions well if the problems are structured, long term uncertainties are translated into short-term objectives and the goals are widely accepted.

\section{The Afsluitdijk in the Netherlands (accommodating asset management)}

This case description is based on Lenferink et al. (2009), Lenferink and Arts (2009) and Janssen et al. (2014).

\section{Characterisation}

In 2006 the famous Afsluitdijk in the Northern Netherlands was disqualified: it did not meet its safety standards for protection against flooding anymore. It was decided that a large reinforcement operation was necessary. In 2007 the national and regional government launched an ambitious project to explore the possibilities for a new, integrative dam. They started a competition for commercial enterprises to investigate available innovative ideas for an integrative dam. Various consortia of private companies participated enthusiastically in this competition, and many charming ideas were developed. However, the realization of these ideas proved to be highly unrealistic, due to high costs and budgetary problems that raised after the financial crisis in 2008. The national government decided to opt for a sober and efficient maintenance project. Regional authorities were disappointed by this decision and started a political lobby, resulting in a budget of the national government (20 million euros) as co-funding for regional investments in supplementary projects to be combined with the reinforcement of the dam. The regional authorities (provinces and municipalities) started a regional program to investigate feasible ideas that could be connected to the reinforcement project.

In this case a long perspective was present, but mainly as a design condition for the reinforcement of the dike. Safety against flooding had to anticipate on a time horizon of at least 50 years. At the same time, this long-term challenge was translated into a very short-term urgency: the dike has to be reinforced in 2021.

\section{Asset management strategy, stakeholder participation and dealing with long term uncertainties}

The asset management strategy can, initially, be defined as open and exploiting. The strategy was aimed at getting 'more value' out the dam by developing integrative ideas which could add new functions to the dam. Governments chose an open dialogue with public and private parties to attract as much new ideas as possible. Furthermore, the executive agency of the Dutch Ministry of Water Works (Rijkswaterstaat) got the responsibility to finalize the reinforcement ultimately in 2021. They defined - in consultation with regional government various moments to connect the reinforcement trajectory and the regional ambition program. An important connecting moment was defined for September 2014. At this moment the public tendering documents had to be finalized and the regional projects that fit in the reinforcement project would be included: the asset manager was willing to facilitate the realization of tidal energy turbines in the scupper-holes of the dike and also gave the necessary permits for a pilot for blue energy. There was a dual participation strategy. The asset manager (Rijkswaterstaat) did its own consultation and information procedure (during the phase after the plan development mainly aimed at informing the public about what is done). Regional authorities dealt with the ambition agenda trying to incorporate ideas and suggestions from stakeholders in various projects they wanted to connect to the reinforcement of the Afsluitdijk.

In this case the long-term is dealt with in an adaptive way. The reinforcement was done with a focus on 2050, after which new measures should be implemented. This should make it possible to consider the need for additional measures when the consequences of climate change are clearer. But it also should enable incorporation of new societal desires and public values which could not be honoured in the short term. The current planning process is thus focused upon a short-term challenge: to take the necessary measures before 2021. This formal deadline puts pressure on the process and creates a strong urgency for stakeholders to participate.

\section{Fit and appropriateness}

The accommodating management strategy of the Afsluitdijk reinforcement was preceded by an open 
participation strategy to develop an integrative dam. This strategy was successful on the one hand, because it generated promising new ideas and enthusiasm with regional and private parties. But, it generated a deadlock when the budget of the asset manager didn't meet the regional expectations, and the integrative dam was focused on a reinforced dam with a reduced integration of regional additions.

From this case the following essentials can be learned:

- this way of asset management can be successful in generating ideas for additional functions and enlarging the public value of the assets. The initial phase of the planning shows new initiatives in this way. In due course, the asset manager lowers the expectations due to budget and planning restraints;

- the open way of management and participation raises expectations which can give tensions with the asset managers constraints (e.g. budget constraints);

- this way of asset management functions well if expectations can be managed within the asset managers constraints. In this project this is done by separating the enforcement process and the regional agenda, and making procedural appointments about how and when to connect both.

\section{Room for the River in the Netherlands (integrated asset management)}

This case description is based on ten Heuvelhof, E. ten et al. (2007), Roovers (2012) and Warner et al. (2012).

\section{Characterisation}

At the end of the last century Dutch government concluded that the traditional way of managing flood protection at its rivers wouldn't be able to sustainably challenge a future with climate change and growing discharges. This traditional way of flood protection existed of periodically reinforcing and improving the dikes alongside the rivers. Government concluded that this would continuously raise water-levels within the rivers and potential damage in case of a flooding. Dikeimprovements were considered part of the problem. Dutch government therefore launched its 'Room for the River'-program. The program was aimed at enlarging the room within the river system to cope with long term rising discharges. The program set some fixed restraints, such as the anticipated long term discharge and a ban on dike-reinforcement. Furthermore, it added an additional goal: improving the spatial quality of the riverine area. Within these restraints all possible solutions were investigated, using a river-basin wide stakeholder participation process. This led to a diversity of possible solutions and finally a large river-basin wide package-deal, including by-passes, dike relocations, retention areas, spatial reservations and subchannels. And all combined with measures that improved spatial quality, such as landscaping and nature restoration. In some projects new housing projects and infrastructure were added to the measures.

In the Room for the River program a long perspective was present: all measures had to anticipate on a time horizon of 100 years (2100). National and regional long term developments were translated into a regional longterm vision which was used as a framework to design and select short-term measures.

\section{Asset management strategy, stakeholder participation and dealing with long term uncertainties}

The asset management strategy can be defined as (mostly) closed and exploring, in some situations open and exploring. The desired and designated functions were set (flood protection and spatial quality). These restraints set the room for solutions. Within these restraints new ways of river management were explored and executed in a river-basin wide participation process. Following the participation process, in some places even new functions were added, such as housing at the dike relocation at Lent. In this, the strategy even had some characteristics of a learning asset management strategy. Within the Room for the River program most stakeholders accepted the measures. At several places projects even consisted of a coproduction between national, regional and local stakeholders. But on some places debate and resistance were high, especially with local stakeholders.

This case deals with a combination of short term measures and long term reservations. The long term is taken into account by anticipating on river discharges until even 2100. Uncertainties are taken into account by choosing a fixed long term design discharge which anticipates on these uncertainties. Furthermore, a long term spatial perspective (2050) was developed, together with the most important stakeholders. Each short-term measure to be taken, should fit into this long term spatial perspective. In Lent, this even let to connecting short term functions (housing) with a long term focused dike relocation. Due to the short-term measures to be taken, stakeholders have a strong urgency to participate.

\section{Fit and appropriateness}

The integrated management strategy of the Room for the River - program was accompanied by a river-basin wide participation strategy to develop new ideas and solutions for existing, pre-set functions. This approach was successful, seen the broad acceptance of measures and the rapidness of a river-basin wide package-deal among national, regional and local authorities. Furthermore, by locally adopting a learning strategy and incorporating 
other functions, acceptance and rapidness was strengthened. Only at some local projects, debate and resistance was fierce.

From this case the following essentials can be learned:

- a closed way of asset-management can be combined with a rather inclusive participation process. In this case the room for solutions given by the dual objective of flood protection and spatial quality was large enough for enabling coproduction of local solutions with stakeholders (Roovers, 2012).

- flexibility contributes to the quality of the stakeholder process: by locally adopting another strategy, the complexity of the challenge can be better addressed and local interests can be better incorporated.

- at the same time, the restraints set in this closed way of asset-management, can limit the room of solutions. Due to these limitations, some interesting solutions can stay behind sight (Roovers, 2012).

\section{The Brouwersdam in the Netherlands (learning asset management)}

This case description is based on Bakker (2014), Van der Weele (2015) and Van Buuren et al. (2015).

\section{Characterisation}

Lake Grevelingen on the border of the Dutch provinces of Zeeland and South Holland faces serious water quality problems. It is one of the sea-arms closed off in the 1950's and 1960's by the Delta Works (in this case the Brouwersdam in 1971). Because of the bad water quality (lack of oxygen in the deep parts) regional governments wanted to invest to preserve the natural qualities of the lake. For this reason, and partly commissioned by the European Water Directive obligations, the national government started several studies to preserve water quality. These studies showed that the most effective solution was to (partly) restore the connection between the lake and the sea, and to bring back tidal dynamics in order to restore natural processes in the lake. At the same time, making a connection also meant adjusting the Brouwersdam by making a breach in the dam. Such a breach is rather expensive. Therefore, the national government decided to start a regional process to explore the possibilities of other functions to be combined with such a gap to create additional possibilities for financing and cost-recovery. This resulted in a dialogue with private companies to explore the possibilities of a tidal power plant (an initiative from regional stakeholders) and a dialogue with regional stakeholders how to realize new functions which are made possible by such a breach. This was complemented with an online e-participation strategy aimed at collecting other ideas what to do with the dam and the lake.

For the whole Southwestern Delta a long-term ambition to restore tidal dynamics is clearly dominating the agenda. Each actor understands that this ambition can be only realized with a stepwise implementation strategy, which makes use of opportunities in the short run. The issue of the water quality is much more a short term urgency (due to Dutch obligations to the European Water Framework Directive), and fits in this long-term ambition.

\section{Asset management strategy, stakeholder participation and dealing with long term uncertainties}

The asset management strategy can be defined as open and exploring. Dutch government openly looked for new functions to be added, using an open and exploring style in consultation with the various regional authorities and private parties. In order to enable realization of the gap in the dam, they were willing to investigate various possibilities for multifunctional solutions and allow for adjustments of the location and the scope of the project. This was deemed necessary because of the budgetary constraints and thus the necessity to find other partners willing to bear costs.

This case deals with relatively short term urgencies and interests. Because of the water quality problems, national government has a strong urgency to take measures. In developing these measures, long term economical and hydrologic developments were taken into account. Because of the short term measures to be taken, and the invitation to participate and develop new functions 'into the gap', there is an urgency for stakeholders to participate. At the same time, the formal plans are surrounded with large uncertainties because the necessary funding is not available.

\section{Fit and appropriateness}

The learning asset management strategy of the Brouwersdam was accompanied by an open dialogue with other parties, leading to new ideas added to the development strategy. This approach was successful because unforeseen additional functions, like tidal energy, were found. Because of the still on-going exploration of the feasibility of the measures, a final judgement of the success of this case, cannot yet be made.

From this case the following essentials can yet be learned:

- An open and exploring way of asset-management can provide new insights and ideas. This type of management needs an open participation strategy: not only looking at new functions, but at coupling problems, solutions and benefits that could enable the realization of a multiple business case. 
- An open explorative style is very productive in the preparatory phases of planning processes, but it is difficult to predict whether it is able to sustain this style in the implementation and maintenance phases.

\section{Discussion}

\section{An overview of participation strategies}

In the previous chapter we described four cases, each representing one of the asset management typologies following our theoretical research. Table 1 overviews the results of the cases.

\section{Coherence and similarities}

At the one hand Table 1 shows a strong congruence between asset management style and participation strategy. This seems logical because the openness of the agenda for participation strongly depends upon the style applied. A closed exploitative style fits better into a participation strategy focused on informing and consulting stakeholders, while an open explorative style is better compatible with a participation strategy aimed at coproduction and learning with stakeholders.

On the other hand, participation strategies show many similarities, regardless of the asset management style. It can be seen that regarding the objectives of the asset manager, mainly an informing participation strategy ('communication') is used. In all cases, much emphasis is put upon informing stakeholders about the necessity of what the asset managers has to do (especially when it comes to flood protection) and minimizing the possible negative impact of asset management investments on people's values and interests. The latter is realized by creating room for consultation with regard to how measures are implemented. Stakeholder participation thus seems an undisputed part of public asset management, at least at an informing level. Participation strategies in the cases with a more closed management style are more focused upon fine-tuning a pre-defined solution, such as dike and dam reinforcement, and on minimizing negative impacts and incorporating local interests in the finally decided-upon solution. However, within certain boundaries, stakeholder participation is also - more positively - aimed at investigating the possibilities to connect stakeholder agendas to the operations of the asset manager ('consulting'). Finally, in the cases with a more open style, stakeholder participation is focused upon creating new ideas and getting input to enrich the envisaged solution ('coproduction').

The used asset management style thus mainly defines the boundaries within which stakeholders can add their ideas and interests. These boundaries are smaller when the asset manager is focused upon exploitation, instead of exploration. But also in case of a more explorative style, stakeholder participation is not unlimited. The asset manager defines the scope for consultation, coproduction and learning, or defines the conditions in which ideas have to fit.

\section{Satisfaction and disappointment}

It is interesting to see that in all four cases the stakeholders' satisfaction with the rate of participation doesn't differ significantly. A possible explanation might be that the asset manager, by choosing a specific asset

Table 1 Overview of the results of the cases

\begin{tabular}{|c|c|c|c|}
\hline Case & Asset management typology & Stakeholder participation & Interaction \\
\hline $\begin{array}{l}\text { Dike } \\
\text { improvements }\end{array}$ & $\begin{array}{l}\text { Monofunctional: asset manager is purely } \\
\text { focused upon securing the primary } \\
\text { function of its assets, in order to stick to } \\
\text { the formal norms with regard to } \\
\text { protection against floods. }\end{array}$ & $\begin{array}{l}\text { Communication aimed at informing the } \\
\text { public and trying to minimize negative } \\
\text { external effects, in order to minimize } \\
\text { resistance and delay during } \\
\text { implementation. Some consultation when } \\
\text { it comes to fine-tuning the measures. }\end{array}$ & $\begin{array}{l}\text { The asset manager was successful in } \\
\text { securing implementation of the dike } \\
\text { enforcements. Support was mainly based } \\
\text { upon a shared sense of urgency to take } \\
\text { measures after the near-floods of } 1993 \text { and } \\
1995 \text {. }\end{array}$ \\
\hline Afsluitdijk & $\begin{array}{l}\text { Accommodating: asset manager focuses } \\
\text { upon maintaining and securing primary } \\
\text { function of asset, but allows other actors } \\
\text { to develop proposals for adding other } \\
\text { functions to the asset. }\end{array}$ & $\begin{array}{l}\text { Communication about the objective of the } \\
\text { reinforcement. Consultation within a } \\
\text { separate process to develop a regional } \\
\text { agenda. Fixed moments to connect the } \\
\text { national and the regional processes. }\end{array}$ & $\begin{array}{l}\text { (Until now) the asset manager is successful } \\
\text { in implementing the enforcement, and } \\
\text { regional actors are able to connect their } \\
\text { projects to the enforcement project. }\end{array}$ \\
\hline $\begin{array}{l}\text { Room for the } \\
\text { River }\end{array}$ & $\begin{array}{l}\text { Integrated: asset manager uses assets to } \\
\text { realize integration of different functions or } \\
\text { values }\end{array}$ & $\begin{array}{l}\text { Communication about the objectives of } \\
\text { the program. Consultation and } \\
\text { coproduction of concrete projects. } \\
\text { Stakeholder participation is aimed at } \\
\text { informing the public, and together with } \\
\text { stakeholders drafting the measures. }\end{array}$ & $\begin{array}{l}\text { The asset manager is successful in realizing } \\
\text { the double ambition (water discharge } \\
\text { capacity and spatial quality) and in most of } \\
\text { the cases stakeholders are satisfied with } \\
\text { the chosen solution. }\end{array}$ \\
\hline Brouwersdam & $\begin{array}{l}\text { Learning: asset manager is willing to } \\
\text { explore new possibilities of value creation } \\
\text { with help of his assets. }\end{array}$ & $\begin{array}{l}\text { Coproduction. Stakeholder participation is } \\
\text { focused upon maximising the room for } \\
\text { possible solutions, to realize and finance a } \\
\text { breach in the dam. }\end{array}$ & $\begin{array}{l}\text { Many ideas are developed, but it is rather } \\
\text { difficult to convince the asset owner (the } \\
\text { minister of Water Works) about the } \\
\text { necessity of contributing to the developed } \\
\text { proposals. }\end{array}$ \\
\hline
\end{tabular}


management style, raises certain expectations about the extent of the participation. In this, the congruence between the chosen style and the participation strategy is important. In more closed styles stakeholders know that the room for maneuver is quite restricted. In more open styles stakeholders expect to have more opportunities to influence the plans. Using these styles raises the chance of disappointment as well, as we saw in the Afsluitdijk case. In this, the rate of urgency seems important too. A high urgency to take measures, for example for flood protection, will incline asset managers to use a more closed style, which might be more accepted by stakeholders due to this urgency. On the other hand this might implicate that an open, explorative style needs less urgency. Too much urgency can hamper the effectiveness of such a style. In general, all cases show that stakeholder participation contributes to better understanding of stakeholders about the goals and urgency of the asset manager. Within the scope for participation - and thus in line with their expectations - stakeholders are satisfied with the results of their input.

\section{Dealing with the long term perspective}

All cases deal with a long term perspective, but have no problems with a lack of urgency of stakeholders to participate. This is because in all cases the asset manager has an urgency to take short-term measures to safeguard long-term ambitions. These short-term measures create the urgency for stakeholders to participate: in some cases (dike reinforcement, Room for the River) because stakeholders want to minimalize the impact of measures, in other cases (Afsluitdijk, Room for the River, Brouwersdam) because they are invited to connect the measures with their own interests and initiatives.

The way the long term perspective is dealt with differs. In the cases dike improvements, Room for the River and Afsluitdijk the long term perspective on climate development is translated into fixed restraints with which short term measures have to deal (a reducing strategy). In the case of the Afsluitdijk this form of reduction is complemented with a more adaptive approach in which additional measures can be decided upon within a shorter time frame (before 2050) - and thus a more anticipating strategy. In the Brouwersdam case the long-term focus results into an explorative approach in which actors explore possible futures and related pathways to these futures (an anticipating strategy).

Within the case dike improvements local ambitions are taken into account when they can be easily combined with the planned reinforcements. Long term developments and ambitions are not taken into account, because of the urgency to enforce the dikes in time and within budget (a reducing strategy). Within the Room for the River Program (which has a longer time horizon for implementing measures), the long term perspective regarding local and regional developments is translated into a long term spatial perspective which serves as a guiding framework to select short-term measures. Furthermore, spatial developments stemming from this perspective are combined with Room for the River measures, as long as the fixed restraints of river discharge capacity are met. This might be considered a combination of an anticipating and reducing strategy. In the case Afsluitdijk local and regional developments and ambitions are combined with the water management goals. Private, local and regional stakeholders are invited to formulate their long-term ambitions and translate them into short term measures (a combination of an anticipating and reducing strategy too). Because local, regional and private stakeholders are participants of an interactive developing process, their ambitions and ideas are connected with the ambitions of the asset manager. But, in this case the time pressure felt by the latter forms a serious constraint to come to real multifunctionality. At the Brouwersdam case the long-term perspective on a more sustainable delta functions as a side condition for the joint exploration: measures have to contribute to this overarching ambition (an anticipation strategy). Table 2 shows an overview of the case results.

\section{Conclusions}

We started this article with questioning the problematic nature of stakeholder participation within asset management dealing with a long term perspective. Based upon the comparative case analyses we can draw some conclusions.

First, we can conclude that - dependent upon the way in which the long-term is dealt with - a specific style of asset management and stakeholder participation seems to be suitable. When a more anticipating strategy is used to deal with uncertainties a more learning asset

Table 2 Overview of stakeholder participation and dealing with long-term uncertainties

\begin{tabular}{|c|c|c|c|c|}
\hline \multirow[t]{2}{*}{ Case } & \multirow[t]{2}{*}{ Style } & \multirow{2}{*}{$\begin{array}{l}\text { Level of participation } \\
\text { Setting the projects goals }\end{array}$} & \multirow{2}{*}{$\begin{array}{l}\text { Level of participation } \\
\text { Developing solutions }\end{array}$} & \multirow{2}{*}{$\begin{array}{l}\text { Dealing with long-term } \\
\text { uncertainties }\end{array}$} \\
\hline & & & & \\
\hline Dike improvements & monofunctional & communication & consultation & reducing \\
\hline Afsluitdijk & accommodating & communication & consultation & reducing (and some anticipating) \\
\hline Room for the River & integrating & communication & consultation (and some co-production) & reducing (and some anticipating) \\
\hline Brouwersdam & learning & coproduction & coproduction & anticipating \\
\hline
\end{tabular}


management style seems appropriate. When a more complexity-reducing strategy is used, a more closed and exploiting style seems appropriate. However, the impact of the long term perspective depends upon the way in which a long-term ambition is translated into a more or less urgent need for short term action. When this urgency is high, there's an urgency for stakeholders to participate too, but the room for participation - and possibly for an anticipating strategy - is low because of high time pressure. When the urgency is low, there is more room for anticipation and for co-developing a long-term perspective in which both the ambitions of the asset manager and the other stakeholders can be entwined. Thus it might by assumed that an effective learning asset management style, including stakeholder participation focused on creating public value and an anticipating strategy, needs less urgency and therefore should be applied early. Application of such a style and strategy while urgency is too high, hampers learning and can cause problems with the expectations of stakeholders.

This brings us to a second conclusion. Applying a specific style successfully also depends upon the phase of the planning process. Effective public asset management might combine an early learning style in the preparatory phase of investments - to anticipate on long term uncertainties and to create more public value - with a more closed style later on, while implementing measures following these public values within time and budget.

As a third conclusion we have seen that connecting the long term perspective with short term measures or initiatives can stimulate stakeholders to participate. Taking short term measures leads to urgency for stakeholders to participate, either to minimize impacts on their own interests, or to connect their own interests with these short term measures. But taking short term measures also minimizes the room for a learning asset management style and an anticipating strategy for longterm uncertainties. Too much urgency leaves stakeholders no time to define their own agenda and to synchronize it with the agenda of the asset manager.

Finally, as asset management focuses on the life-cycle of assets and needs to be connected with organizational goals, public asset management seems to ask for a permanent and institutionalized dialogue on an organizational level between asset manager and stakeholders. This dialogue needs to alter between the different styles of asset management, according to the specific needs of assets, ambitions and urgencies at stake.

\section{Competing interests}

The authors declare that they have no competing interests.

\section{Authors' contributions}

Article was a co-production of authors, in all contributions. Both authors read and approved the final manuscript.

\section{Acknowlegdments}

None.

\section{Author details}

${ }^{1}$ Antea Group, Oosterhout, Netherlands. ${ }^{2}$ Saxion University of Applied Science, Deventer, the Netherlands. ${ }^{3}$ Department of Public Administration, Erasmus University Rotterdam, Rotterdam, the Netherlands.

Received: 14 September 2015 Accepted: 5 January 2016

Published online: 20 January 2016

\section{References}

Arnstein A (1969) A ladder of citizenship participation. J Am Inst Plann 26:216-233

Bakker H (2014) Getijdencentrale Brouwersdam. Governance van een netwerk met als doel een gezond meer. Master Thesis Public Administration, Erasmus University Rotterdam. [in Dutch]

Baskarada, S., J. Gao, A. Koronios (2006) Centre for integrated engineering assets management (CIEAM); Witold Abramovicz (ed.); Business Information System; Proceedings of BIS, 2006, Poznán, Poland

Bressers H, Lulofs K (2010) Governance and complexity in water management: Creating cooperation through boundary spanning strategies. Edward Elgar Publishing

Bruijn, H. de, E. ten Heuvelhof (2007) Management in netwerken, Over veranderen in een multi-actor-context; Geheel Herziene Druk [In Dutch]

BS EN ISO 9001:2008 (2008) Quality management systems. Requirements Published: November 2008

van Buuren MW, Driessen PPJ, van Rijswick HJFM, Teisman GR (2014) Towards legitimate governance strategies for climate adaptation. Combining insights from legal, planning and democratic perspectives. Reg Environ Change 14(3):1021-1033

van Buuren MW, Duijn M, Grotenbreg S, van Leeuwen C, Klijn E-H, Boons F (2015) De governance van energiedijken. Stapstenen en ontwikkelpaden voor de integratie van waterkeringen en duurzame energieproductie. Erasmus Universiteit Rotterdam

Dewulf, G., Hartmann, A., Schraven, D. (2010) Denk vooruit maar plan met mate; Hubholland. Magazine: Infrastructurele Netwerken Eur, 3 (1). [In Dutch]

van Dorsser, C (2015) Very Long Term Development of the Dutch Inland Waterway Transport System Policy Analysis, Transport Projections, Shipping Scenarios, and a New Perspective on Economic Growth and Future Discounting; Thesis, Technical University of Delft, ISBN: 978-90-5584-188-2; Delft

Driessen, A P.P.J., .A.J. de Gier (1997) Uit nood geboren; Een bestuurlijk-juridische evaluatie van de dijkversterkingen en kadenaanleg onder de Deltawet Grote Rivieren. 's Gravenhage, [In Dutch]

Edelenbos J, Klijn EH (2006) Managing stakeholder involvement in decision making: a comparative analysis of six interactive processes in the Netherlands. J Public Adm Res Theory 16(3):417-446

van Eeten, M. van, (1997) Sprookjes in rivierenland. Beleidsverhalen over wateroverlast en dijkversterking; Beleid \& Maatschappij; no 1., 1997.

El-Akruti K, Dwight R (2010) A framework for the engineering asset management system. J Qual Maintenance Eng 19(4):398-412

Eshuis, J., Buuren, M.W. van (2014) Innovations in water governance: the importance of time. Int Rev Adm Sci (doi: 10.1177/0020852313514518)

Falls I, Haas R, McNeill S, Tighe S (2001) Asset management and pavement management: Using common elements to maximize overall benefits, Transportation Research Record, Paper No. 01-2415

van Heezik A (2007) Strijd om de rivieren. 200 jaar rivierenbeleid in Nederland of de opkomst en ondergang van het streven naar de normale rivier; Haarlem/ Den Haag 2008ISBN/EAN: 978-90-813275-2-7 Uitgever Beleidsresearch.nl | Van Heezik Beleidsresearch, Haarlem

Heuvelhof, E. ten, H. de Bruijn, M. de Wal, M. Kort, M. van Vliet, M. Noordink, B. Böhm (2007) Procesevaluatie totstandkoming PKB Ruimte voor de Rivier; Berenschot

Franssen, R., H. v.d. Berg, R. v.d. Brugge, J. v.d. Heijden, B. Ottow (2013) Advies voor de VONK-systematiek over interactie met de omgeving; Deltares, Delft. [In Dutch]

Frolov V, Megel D, Bandara W, Sun Y, Ma L (2009) Building an ontology and process architecture for engineering asset management. Proceeding of the 4th World Congress on Engineering Asset Management, (28-30 of Sept., Marriott Athens Ledra Hotel, Athens) 
Herder, P., Wijnia Y (2012) A systems view on infrastructure asset management; In: Asset Management; The state of the art in Europe from a life cycle perspective; van der Lei, T., P. Herder, Y. Wijnia (Editors); Springer; ISBN 978-94-007-2723-6

Hoppe R, Hisschemöller M (1996) Coping with Intractable Controversies: The Case for Problem Structuring in Policy Design and Analysis; January 1996

Irvin, R. A., Stansbury J (2004) Citizen Participation in Decision Making: Is It Worth the Effort? Public Adm Rev 64(1):55-56. doi:10.1111/j.1540-6210.2004.00346.x

Janssen SK, Mol AP, van Tatenhove JP, Otter HS (2014) The role of knowledge in greening flood protection. Lessons from the Dutch case study future Afsluitdijk. Ocean Coastal Manage 95:219-232

Koppejan J, Klijn E-H (2004) Managing uncertainties in Networks. A network approach to problem solving and decision making, Routledge, London

Lenferink S, Struiksma H, Sukkar G, Oldenkamp A (2009) Evaluatie Marktverkenning Afsluitdijk. Rijksuniversiteit Groningen, Groningen [In Dutch]

Lenferink S, Arts J (2009) Elverding, de markt en de kunst van het dromen. Rijksuniversiteit Groningen, Groningen [in Dutch]

Meurs, R. van (2002) De laatste dagen van een boerenrepubliek. Polderdistrict Betuwe, vijfentwintig jaar werk en strijd. ISBN 978.90.5345.219.6; [In Dutch]

Moon FL, Aktan AE, Furuta H, Dogaki M (2009) Governing issues and alternate resolutions for a highway transportation agency's transition to asset management. Struct Infrastructure Eng 5(1):25-39

van Overmeeren ARNE (2011) The area-based planning process of Dutch housing associations. In: Management and Innovation for a Sustainable Built Environment MISBE 2011. June 20-23, 2011. CIB, Working Commissions W55, W65, W89, W112; ENHR and AESP, Amsterdam, The Netherlands

Reed, M.S., (2008) Stakeholder participation for environmental management: A literature review; Sustainability Research Institute, School of Earth and Environment, University of Leeds. Elsevier Ltd. All rights reserved. doi:10. 1016/j.biocon.2008.07.014

Roovers G (2012) De systeembenadering van professionals als drager van de besluitvorming in het rivierbeheer; Technical University of Delft; Phd; ISBN: 978-90-5335-628. [In Dutch]

Roovers G, van Buuren MW (2014) Van investeren naar evolueren: Wat eigentijds asset management betekent voor de organisatie van het waterbeheer. In: Water Governance., december 2014 [in Dutch]

Rotmans J, Loorbach D, van der Brugge R (2005) Transitiemanagement en duurzame ontwikkeling; Co-evolutionaire sturing in het licht van complexiteit. Beleidswetenschap 19(nr 2):3-23 [In Dutch]

Rowe G, Frewer $L$ (2000) Public participation methods: a framework for evaluation in science. Technol Hum Values 25:3-29

Schraven DFJ, Hartmann A, Dewulf GPMR (2013) Research orientations towards 'management' of infrastructure assets: an intellectual structure approach. Struct Infrastructure Eng 11(2):73-96. doi:10.1080/15732479.2013.848909

Teisman G (2007) Publiek Management op de grens van orde en chaos; Sdu Uitgevers, Den Haag. [In Dutch]

Teisman GR, van Buuren MW, Edelenbos J, Warner JF (2013) Water governance: Facing the limits of managerialism, determinism, water-centricity, and technocratic problem-solving. Int J Water Governance (print) 1(1-2):1-11

Too EG (2010) A framework for strategic infrastructure asset management. Eng Asset Manage Rev 1:31-62. doi:10.1007/978-1-84996-178-3_3

Voskamp IM, Van de Ven FHM (2015) Planning support system for climate adaptation: composing effective sets of blue-green measures to reduce urban vulnerability to extreme weather events. Build Environ 83:159-167

Warner JF, van Buuren MW, Edelenbos J (eds) (2012) Making space for the river. Governance experiences with multifunctional river flood management in the US and Europe. IWA Publishing, London

van der Weele F (2015) Tussen vastleggen en openhouden. Master Thesis Public Administration, Erasmus University Rotterdam. [In Dutch]

\section{Submit your manuscript to a SpringerOpen ${ }^{\bullet}$ journal and benefit from:}

- Convenient online submission

- Rigorous peer review

- Immediate publication on acceptance

- Open access: articles freely available online

- High visibility within the field

- Retaining the copyright to your article

Submit your next manuscript at $>$ springeropen.com 